\title{
Genetics of cytosolic phosphoglucose isomerase (PGI) variation in the Amazonian tree Pseudobombax munguba (Bombacaceae)
}

\author{
ROGÉRIO GRIBEL* \& RICHARD J. ABBOTT† \\ Departamento de Ecologia, Instituto Nacional de Pesquisas da Amazônia, Caixa Postal 478, 69011-970 Manaus, AM, \\ Brazil and + Division of Environmental and Evolutionary Biology, School of Biological and Medical Sciences, \\ University of St. Andrews, Fife KY16 9TH, Scotland, U.K.
}

\begin{abstract}
A genetic analysis of cytosolic phosphoglucose isomerase (PGI) variation in the tropical tree Pseudobombax munguba (Bombacaceae) was carried out in one population from Central Amazon. It was shown that cytosolic PGI variation is controlled by two diallelic loci (Pgi-2 and $P g i-3)$. All nine possible enzyme phenotypes produced by allelic variation at these two loci were easily identified on gels stained for PGI. Progeny analysis from cross-pollinated families revealed that the two loci assorted independently and exhibited disomic inheritance, suggesting that allopolyploidy may have been the cause of the duplication of the cytosolic PGI gene in this species.
\end{abstract}

Keywords: Bombacaceae, gene duplication, isozymes, PGI, Pseudobombax, tropical trees,

\section{Introduction}

The genus Pseudobombax (Bombacaceae) is exclusively neotropical with 20 species distributed from south Brazil, Paraguay and Argentina to Central America (Robyns, 1963; Aubreville, 1975). Pseudobombax munguba is the only species in the genus that occurs in the extensive quaternary floodplain terrains of the Amazon, spreading from the Peruvian and Colombian Amazonian lowlands to the Amazon River mouth region in the Pará and Amapá States, Brazil. The species is a bat-pollinated tree that grows up to $40 \mathrm{~m}$ high and occurs typically along the sedimentary basins of the 'white-water' rivers in the seasonally inundated habitat called 'várzea' (Pires, 1974; Pires \& Prance, 1985). Pseudobombax munguba is a key species in the várzea habitat, producing annually great quantities of small seeds rich in oils and proteins consumed by a large number of economically important regional fishes. The high chromosome number of $P$. munguba $(2 n=84$; Baum \& Oginuma, 1994) and the evolutionary history of the Bombacaceae family suggest a palaeopolyploid origin for the species. However, no information about the species' ploidy level or its putative ancestors is available.

\footnotetext{
${ }^{*}$ Correspondence.
}

(c) 1996 The Genetical Society of Great Britain.
The current work was initiated to resolve a reliable genetic marker system for use in studies of the breeding and mating system of $P$. munguba. Several recent investigations of the mating system of tropical trees have used isozyme markers to estimate rates of outcrossing (O'Malley \& Bawa, 1987; O'Malley et al., 1988; Murawski \& Hamrick, 1991, 1992; Murawski et al., 1990, 1994; Alvarez-Buylla \& Garay, 1994; Hall et al., 1994; Boshier et al., 1995). However, the markers used in these studies were not normally subject to a formal genetic analysis of inheritance (but see Alvarez-Buylla \& Garay, 1994), probably because of the operational difficulties in hand pollinating tall rain forest trees.

In this paper we report the results of a genetic analysis of the cytosolic phosphoglucose isomerase (PGI) phenotypes resolved in a population of $P$. munguba in the Central Amazon. The analysis has led to the detection of two diallelic loci controlling the cytosolic PGI variation in $P$. munguba and the resolution of two sets of genetic markers that are suitable for future studies of the reproductive biology of the species.

\section{Materials and methods}

\section{The study site and the trees}

The study site was located in the Ponta do Catalão, a peninsular area where the Rio Negro and Rio 
Solimões join to form the Amazon river, about 4.5 $\mathrm{km} \mathrm{SE}$ of the city of Manaus (about $03^{\circ} 08^{\prime} \mathrm{S}$, $60^{\circ} 00^{\prime} \mathrm{W}$ ), Amazonas state, Brazil. The area, covered by the 'várzea' vegetation, is annually inundated for 4-7 months during the period of high waters. In this area $P$. munguba is one of the dominant arboreal species.

\section{Electrophoretic procedures}

Of the seven enzyme systems initially assayed (phosphoglucose isomerase, phosphoglucomutase, alcohol dehydrogenase, glucose-6-phosphate dehydrogenase, malate dehydrogenase, esterase and peroxidase), only PGI was investigated further. This enzyme presented clear, repeatable bands and polymorphisms on starch gels. PGI is a dimeric enzyme that catalyzes the reversible isomeration of glucose6-phosphate and fructose-6-phosphate (Stryer, 1988). In plants, PGI is usually compartmentalized in the cytoplasm and in the chloroplast (Scharrenberger et al., 1975; Weeden \& Gottlieb, 1980a,b; Weeden, 1983). The plastid PGIs are generally more anodal and exhibit less electrophoretic variability than PGI from the cytoplasm (Gottlieb \& Weeden, 1981).

Leaf tissue samples (about $1 \mathrm{~cm}^{2}$ ) were crushed with a glass rod in a chilled microtiter plate using the extraction buffer of Mitton et al. (1979). Filter paper wicks containing the crude leaf extract were inserted in a 12 per cent $(\mathrm{w} / \mathrm{v})$ starch gel for horizontal electrophoresis. Morpholine-citrate electrode and gel buffers (system 2 in Wendel \& Weeden, 1989) were used in the electrophoresis after modifying the $\mathrm{pH}$ to 8 . An electric current of $40 \mathrm{~mA}$ (about $250 \mathrm{~V}$ ) was applied to the gels for $4.5 \mathrm{~h}$ before they were sliced and stained. The staining protocol for PGI followed that described by Wendel \& Weeden (1989).

\section{Analysis of $P G /$ variation}

Adults Fifty-six $P$. munguba trees were randomly chosen for analysis. Branches with young leaves were collected from trees in the early morning, transported to the laboratory, and analysed up to $2 \mathrm{~h}$ later. Enzymes were extracted from fresh young leaf tissue.

Seedlings Seeds contained in 30 open-pollinated fruits (one fruit per tree) and also in 14 fruits produced following hand cross-pollinations (see below) were collected at maturity approximately 3 months after flower anthesis. Pairs of trees used in the cross-pollinations had been previously assayed and were of known PGI phenotype. Seeds from each fruit were washed with 30 per cent solution of sodium hypochlorite, rinsed, and sown in Petri dishes on moist filter paper. Nearly all seeds germinated in 2-3 days. Enzymes were extracted from the cotyledons of seedlings 7-10 days after germination. A total of 754 seedlings from open-pollinated and 668 seedlings from hand cross-pollinated fruits was analysed.

\section{Controlled pollinations}

The lower branches of trees were reached by canoe during the period of 'high waters'. Floral buds were opened, emasculated and enclosed in paper bags shortly before anthesis at approximately $18.30 \mathrm{~h}$. Massive loads of self- (in self-pollinations) or crosspollen (in cross-pollinations) were deposited on stigmas at around $20.00 \mathrm{~h}$. Flowers were then rebagged until 10.00-11.00 h the following morning. Pseudobombax munguba produced no fruits following self-pollination (fruit-set $=0$ per cent, $N=406$ selfpollinated flowers) and, consequently, only seeds from fruits resulting from hand cross-pollinations and open-pollinations were analysed.

\section{Results}

\section{Cytosolic PGI phenotypes}

Nine different PGI phenotypes (Fig.1) were resolved among the 1478 individuals assayed (56 adult trees, plus 754 and 668 seedlings from open- and crosspollinated fruits, respectively). All individuals shared a single band in the most anodal zone (approximately $55 \mathrm{~mm}$ from the origin). This enzyme, designated PGI-1, was not well resolved on most gels, and, by analogy with the findings of studies on other plant species, was inferred to be the chloroplastic PGI (Schnarrenberger et al., 1975; Weeden \& Gottlieb, 1980b; Gottlieb \& Weeden, 1981; Gottlieb 1982).

The less anodal zone presented phenotypes with one to six well-resolved bands of several staining intensities. These bands were separated at regular distances of $3 \mathrm{~mm}$, except the fifth and the sixth bands which were separated by $6 \mathrm{~mm}$. Isozymes resolved in the less anodal zone have been reported as variant forms of cytosolic PGI in other plants (Gottlieb \& Weeden, 1981). High levels of isozyme variability for cytosolic PGI are usually the result of a gene duplication (Adams \& Allard, 1977; Gottlieb, 1977, 1982; Goldring et al., 1985; Lack \& Kay, 1986; 


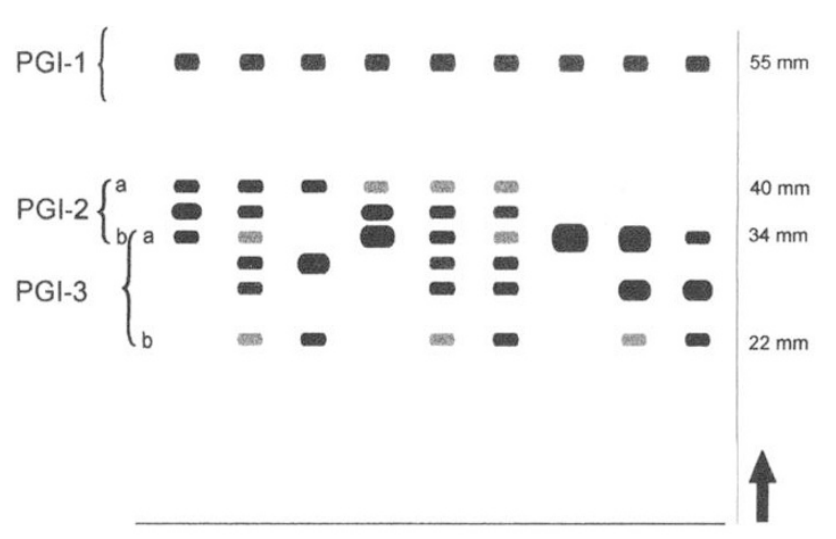

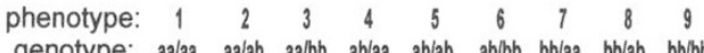

Fig. 1 Electrophoretic phenotypes and suggested genotypes at Pgi-2/Pgi-3 in Pseudobombax munguba.

Lumaret, 1986; Pascual et al. 1988; Cai \& Chinnappa, 1989; Rovira et al., 1993).

A two-locus diallelic model explains the variability of cytosolic PGI phenotypes observed in $P$. munguba. It is proposed, therefore, that the first locus, designated Pgi-2, has two alleles $\left(P g i-2^{a}\right.$ and $\left.P g i-2^{b}\right)$ which code for two subunits (PGI-2a and PGI-2b) with electrophoretic mobilities of $40 \mathrm{~mm}$ and $34 \mathrm{~mm}$ from the origin, respectively (Fig. 1). These two enzyme subunits associate, in heterozygous individuals (genotype $P g i-2^{a b}$ ), to form an intralocus hybrid heterodimer that migrates halfway between the two homodimers.

The second set of cytosolic PGI enzymes, designated PGI-3, may be considered to be coded by the Pgi-3 locus. Two alleles at this locus (Pgi- $3^{a}$ and Pgi- $3^{b}$ ) encode two subunits (PGI-3a and PGI-3b) which migrate 34 and $22 \mathrm{~mm}$ from the origin, respectively. The intralocus heterodimer produced by these two alleles in heterozygotes exhibits an electrophoretic mobility that is intermediate ( 28 $\mathrm{mm}$ ) to that of the two homodimers. The overlap of the faster enzyme of the Pgi-3 (PGI-3a) and the slower of the Pgi-2 (PGI-2b) at $34 \mathrm{~mm}$ from the origin was not exact. In gels that were run for $5 \mathrm{~h}$ (instead of the standard $4.5 \mathrm{~h}$ ) the two enzymes could be separated, with the PGI-3a enzyme migrating to a slightly more anodal position than PGI- $2 b$.

It was interpreted that interlocus hybrid enzymes (interlocus heterodimers), showing intermediate mobility, were formed between the following pairs of homodimers: PGI-2a/PGI-3a, PGI-2a/PGI-3b and PGI-2b/PGI-3b. These heterodimers were located on gels approximately midway between the respective homodimers (at 37,31 and $28 \mathrm{~mm}$ from the origin, respectively). An interlocus heterodimer between PGI-2b and PGI-3a was not observed on most gels because of the overlap of the two homodimeric enzymes, but was visible on gels which ran for more than $5 \mathrm{~h}$.

The model described above allows genotypes to be assigned to each of the nine PGI phenotypes resolved, in the manner shown in Fig. 1. The relative staining intensities of the bands, which were clearly distinguishable on all gels, were crucial to the correct designation of genotypes.

\section{Progeny analysis}

Based on the two-locus diallelic model proposed above, Pgi-2 and Pgi-3 genotypes were assigned to maternal trees and the offspring of 30 open-pollinated families surveyed (Table 1). Twenty-two trees were found to exhibit phenotype 1 (Fig. 1) and were classified, therefore, to be of Pgi- $2^{a a}$, Pgi- $3^{a a}$ genotype. Five other trees were also homozygous for Pgi- $2^{a}$, but were either heterozygous or homozygous for the $b$ allele at Pgi-3. Because of the rarity in the population of $b$ alleles at both loci, only two trees were homozygous for either Pgi-2 $2^{b}$ or Pgi- $3^{b}$.

Offspring genotypes within each open-pollinated family array (Table 1) were always in accordance with those expected, based on the genotype assigned to the mother tree and the genotypes assigned to other trees (potential pollen donors) within the population sample. In no instance, therefore, was an offspring genotype recorded that could not have arisen in the family of a maternal tree of assigned genotype.

The results of the controlled crossing programme are presented in Table 2. Offspring phenotypes are illustrated in Fig. 2 and show the ease with which different phenotypes were identified in progeny arrays even when differences were based simply on the relative staining intensities of particular bands. Only one of the nine PGI phenotypes presented in Fig. 1 was not generated by the crosses undertaken. This was the single-banded phenotype 7 produced by individuals of genotype Pgi- ${ }^{b b} P g i-3^{a a}$. However, five seedlings with this phenotype were detected among the open-pollinated progenies surveyed (Fig. 2i and Table 1). In contrast, only one seedling homozygous for the rarest allele at both loci (phenotype 9, produced by individuals of genotype Pgi- $2^{b b} P g i-3^{b b}$ ) was detected among 754 seedlings surveyed from the field (Table 1). Six seedlings with this phenotype, however, were recovered from the cross between genotypes Pgi-2 ${ }^{a b} P g i-3^{a b}$ and $P g i-2^{a b} P g i-3^{b b}$ (Table 2).

An examination of the segregation data (Table 2) 

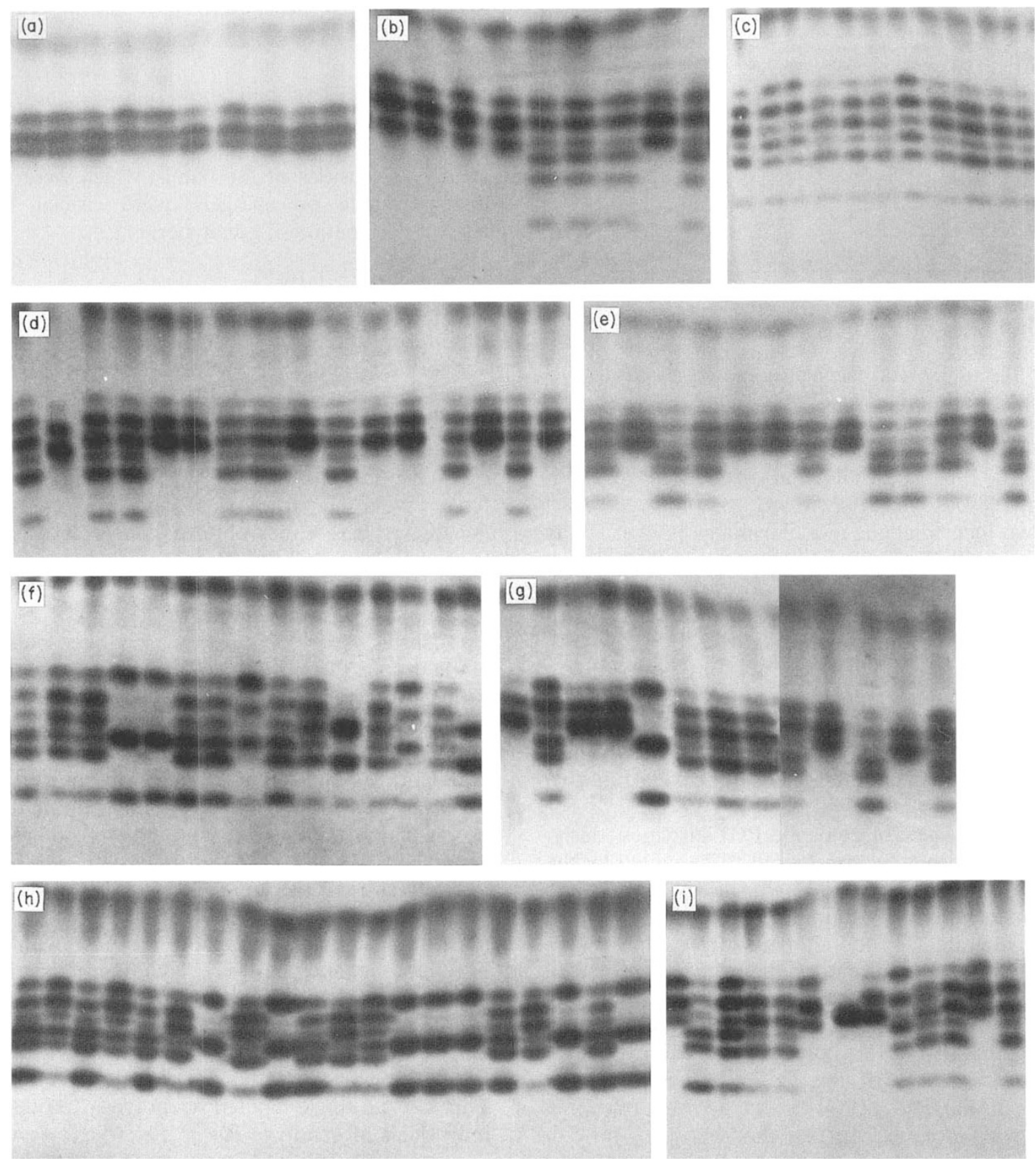

Fig. 2 PGI zymograms of progenies from cross-pollinations (a-h) and open-pollination (i) of Pseudobombax munguba. Parental trees are noted as Pgi-2/Pgi-3 genotypes. Progeny phenotype numbers and corresponding genotypes are as given in Fig. 1. (a) $a a / a a \times a a / a a$; progeny exhibiting the 'fixed heterozygous' banding pattern of the phenotype 1 ; (b) $a a / a a \times a a /$ $a b$; progeny phenotypes: $1 / 1 / 1 / 1 / 2 / 2 / 2 / 1 / 2 ;$ (c) $a a / a a \times a b / b b$; progeny phenotypes: $5 / 2 / 2 / 5 / 5 / 5 / 2 / 5 / 5 / 5 / 5 ;$ (d) $a a / a a \times a a / a b$; progeny phenotypes: 5/4/5/5/4/4/5/5/4/5/4/4/5/4/5/4; (e) $a a / a b \times b b / a b$; progeny phenotypes: 5/4/6/5/4/4/5/4/6/6/5/4/6; (f) $a b / a b \times a b / b b$; progeny phenotypes: $6 / 5 / 5 / 3 / 3 / 6 / 6 / 2 / 6 / 5 / 8 / 5 / 2 / 5 / 9 ;(\mathrm{g}) a a / a b \times a b / a b ;$ progeny phenotypes:

$4 / 2 / 4 / 4 / 3 / 5 / 5 / 5 / 2 / 1 / 6 / 4 / 2$; (h) $a a / a b \times a b / b b$; progeny phenotypes: $6 / 2 / 6 / 2 / 6 / 5 / 3 / 5 / 3 / 6 / 5 / 2 / 3 / 3 / 3 / 6 / 5 / 3 / 6 / 3$; (i) $a b / a b$; progeny phenotypes: $1 / 6 / 2 / 5 / 5 / 1 / 7 / 4 / 2 / 5 / 5 / 1 / 5$. 
Table 1 Maternal and offspring genotypes for 30 open-pollinated families of Pseudobombax munguba at the Pgi-2 and Pgi-3 loci

\begin{tabular}{|c|c|c|c|c|c|c|c|c|c|c|c|}
\hline \multirow[b]{2}{*}{ Tree } & \multirow{2}{*}{$\begin{array}{l}\text { Genotype at } \\
\text { Pgi-2/Pgi-3 }\end{array}$} & \multicolumn{10}{|c|}{ Offspring genotypes at $P g i-2 / P g i-3^{*}$} \\
\hline & & $a a / a a$ & $a a / a b$ & $a a / b b$ & $a b / a a$ & $a b / a b$ & $a b / b b$ & $b b / a a$ & $b b / a b$ & $b b / b b$ & Total \\
\hline 0 & $a a / a a$ & 22 & 3 & - & 0 & 0 & - & - & - & - & 25 \\
\hline 3 & $a a / a a$ & 25 & 0 & - & 0 & 0 & - & - & - & - & 25 \\
\hline $3 \mathrm{~A}$ & $a a / a a$ & 13 & 7 & - & 5 & 0 & - & - & - & - & 25 \\
\hline $3 \mathrm{~B}$ & $a a / a a$ & 12 & 4 & - & 8 & 0 & - & - & - & - & 24 \\
\hline $5 \mathrm{~B}$ & $a a / a a$ & 24 & 0 & - & 0 & 0 & - & - & - & - & 24 \\
\hline $5 \mathrm{D}$ & $a a / a a$ & 9 & 6 & - & 5 & 3 & - & - & - & - & 23 \\
\hline $5 \mathrm{~F}$ & $a a / a a$ & 21 & 1 & - & 1 & 2 & - & - & - & - & 25 \\
\hline 6 & $a a / a a$ & 24 & 0 & - & 0 & 0 & - & - & - & - & 24 \\
\hline $8 \mathrm{~A}$ & $a a / a a$ & 11 & 10 & - & 2 & 1 & - & - & - & - & 24 \\
\hline $10 \mathrm{~A}$ & $a a / a a$ & 15 & 3 & - & 3 & 2 & - & - & - & - & 23 \\
\hline $10 \mathrm{~B}$ & $a a / a a$ & 22 & 1 & - & 1 & 1 & - & - & - & - & 25 \\
\hline 10D & $a a / a a$ & 18 & 6 & - & 0 & 0 & - & - & - & - & 24 \\
\hline 12 & $a a / a a$ & 18 & 0 & - & 4 & 3 & - & - & - & - & 25 \\
\hline 17 & $a a / a a$ & 24 & 0 & - & 0 & 0 & - & - & - & - & 24 \\
\hline 21 & $a a / a a$ & 16 & 6 & - & 2 & 0 & - & - & - & - & 24 \\
\hline N5 & $a a / a a$ & 16 & 3 & - & 2 & 3 & - & - & - & - & 24 \\
\hline N12 & $a a / a a$ & 14 & 8 & - & 1 & 0 & - & - & - & - & 23 \\
\hline N13 & $a a / a a$ & 17 & 3 & - & 5 & 0 & - & - & - & - & 25 \\
\hline M2 & $a a / a a$ & 20 & 2 & - & 0 & 2 & - & - & - & - & 24 \\
\hline M8 & $a a / a a$ & 17 & 2 & - & 3 & 2 & - & - & - & - & 24 \\
\hline $\mathrm{A} 2$ & $a a / a a$ & 11 & 9 & - & 3 & 0 & - & - & - & - & 23 \\
\hline B3 & $a a / a a$ & 19 & 0 & - & 6 & 0 & - & - & - & - & 25 \\
\hline $11 \mathrm{~A}$ & $a a / a b$ & 10 & 9 & 2 & 1 & 1 & 1 & - & - & - & 24 \\
\hline 22 & $a a / a b$ & 9 & 9 & 4 & 0 & 2 & 1 & - & - & - & 25 \\
\hline B1 & $a a / a b$ & 9 & 6 & 3 & 3 & 4 & 0 & - & - & - & 25 \\
\hline N2 & $a a / a b$ & 1 & 5 & 3 & 5 & 10 & 1 & - & - & - & 25 \\
\hline N9 & $a a / b b$ & - & 12 & 5 & - & 8 & 0 & - & - & - & 25 \\
\hline $5 \mathrm{E}$ & $a b / a a$ & 5 & 0 & - & 17 & 1 & - & 2 & 0 & - & 25 \\
\hline W & $a b / a b$ & 6 & 3 & 0 & 5 & 8 & 1 & 1 & 1 & 0 & 25 \\
\hline N3 & $b b / a b$ & - & - & - & 18 & 18 & 6 & 2 & 3 & 1 & $\begin{array}{r}48 \\
754\end{array}$ \\
\hline
\end{tabular}

*Zero value is included when the genotype indicated could have arisen amongst the offspring of a given tree, but it was not found.

showed that deviations from Mendelian expected ratios were not significant for single-locus or twolocus segregations in any of the families of the 14 crosses examined. Thus, the segregations were as expected based on the two-locus diallelic model that is proposed for the variation of PGI-2 and PGI-3 resolved in $P$. munguba.

\section{Discussion}

The results of the present study support the hypothesis that cytosolic PGI variation in $P$. munguba is controlled by two diallelic loci that assort independently of each other and exhibit disomic inheritance. Previous studies on the mode of inheritance of phosphoglucose isomerase (PGI) variation in plants have shown that in many species the observed segregation pattern does not depart significantly from Mendelian expectations (Adams \& Allard, 1977; Gottlieb, 1977; Torres et al., 1985; Prentice \& Giles, 1993; Rovira et al., 1993), whereas others have shown that segregation distortion sometimes occurs (Adams \& Joly, 1980; Strauss \& Conkle, 1986; Aravanopoulos et al., 1993). PGI duplicated genes have been reported to assort independently in Clarkia (Gottlieb, 1977, 1982; Gottlieb \& Weeden, 1979) and Corylus (Rovira et al., 1993), but were found to be linked in studies on the auto- 
Table 2 Genotype segregation for Pgi-2 and Pgi-3 in the $\mathrm{F}_{1}$ progenies from crosses of Pseudobombax munguba

\begin{tabular}{|c|c|c|c|c|c|c|}
\hline $\begin{array}{l}\text { Parent } \\
\text { trees }\end{array}$ & $\begin{array}{c}\text { Parent } \\
\text { genotypes }\end{array}$ & $\begin{array}{l}\text { Expected } \\
\text { progeny }\end{array}$ & $\begin{array}{l}\text { Expected } \\
\text { ratio }\end{array}$ & $\begin{array}{l}\text { Observed } \\
\text { distribution }\end{array}$ & $\begin{array}{l}\text { Chi- } \\
\text { square }\end{array}$ & $\begin{array}{c}P \\
\text { value }\end{array}$ \\
\hline $16 \times 10 \mathrm{C}$ & $a a / a a \times a a / a a$ & $a a / a a$ & 1 & 48 & & \\
\hline $6 \times 4$ & $a a / a a \times a a / a a$ & $a a / a a$ & 1 & 48 & & \\
\hline \multirow[t]{2}{*}{$5 \mathrm{~F} \times 12 \mathrm{~B}$} & $a a / a a \times a b / a a$ & $a a / a a$ & 1 & 37 & 0.36 & 0.549 \\
\hline & & $a b / a a$ & 1 & 32 & & \\
\hline \multirow[t]{2}{*}{$12 \times \mathrm{N} 2$} & $a a / a a \times a a / a b$ & $a a / a a$ & 1 & 25 & 0.19 & 0.663 \\
\hline & & $a a / a b$ & 1 & 22 & & \\
\hline \multirow[t]{2}{*}{$10 \mathrm{C} \times \mathrm{N} 2$} & $a a / a a \times a a / a b$ & $a a / a a$ & 1 & 25 & 0.82 & 0.365 \\
\hline & & $a a / a b$ & 1 & 19 & & \\
\hline \multirow[t]{2}{*}{$0 \times 11$} & $a a / a a \times a b / b b$ & $a a / a b$ & 1 & 23 & 0.08 & 0.777 \\
\hline & & $a b / a b$ & 1 & 25 & & \\
\hline \multirow[t]{2}{*}{$4 \times 1$} & $a a / a a \times a b / b b$ & $a a / a b$ & 1 & 9 & 1.96 & 0.162 \\
\hline & & $a b / a b$ & 1 & 16 & & \\
\hline \multirow[t]{2}{*}{$5 \mathrm{~A} \times \mathrm{N} 3$} & $a a / a a \times b b / a b$ & $a b / a a$ & 1 & 22 & 0.33 & 0.566 \\
\hline & & $a b / a b$ & 1 & 26 & & \\
\hline \multirow[t]{3}{*}{$\mathrm{A} 1 \times \mathrm{N} 3$} & $a a / a b \times b b / a b$ & $a b / a a$ & 1 & 14 & 1.13 & 0.568 \\
\hline & & $a b / a b$ & 2 & 20 & & \\
\hline & & $a b / b b$ & 1 & 12 & & \\
\hline \multirow{3}{*}{$\mathrm{N} 4 \times \mathrm{N} 3$} & $a a / a b \times b b / a b$ & $a b / a a$ & 1 & 11 & 0.46 & 0.795 \\
\hline & & $a b / a b$ & 2 & 23 & & \\
\hline & & $a b / b b$ & 1 & 14 & & \\
\hline \multirow[t]{4}{*}{ B1 $\times 11$} & $a a / a b \times a b / b b$ & $a a / a b$ & 1 & 10 & 3.83 & 0.280 \\
\hline & & $a a / b b$ & 1 & 13 & & \\
\hline & & $a b / a b$ & 1 & 8 & & \\
\hline & & $a b / b b$ & 1 & 17 & & \\
\hline \multirow[t]{4}{*}{$11 \times \mathrm{N} 2$} & $a b / b b \times a a / a b$ & $a a / a b$ & 1 & 16 & 1.07 & 0.784 \\
\hline & & $a a / b b$ & 1 & 13 & & \\
\hline & & $a b / a b$ & 1 & 15 & & \\
\hline & & $a b / b b$ & 1 & 11 & & \\
\hline \multirow[t]{6}{*}{$\mathrm{W} \times 11$} & $a b / a b \times a b / b b$ & $a a / a b$ & 1 & 9 & 4.43 & 0.489 \\
\hline & & $a a / b b$ & 1 & 4 & & \\
\hline & & $a b / a b$ & 2 & 10 & & \\
\hline & & $a b / b b$ & 2 & 14 & & \\
\hline & & $b b / a b$ & 1 & 3 & & \\
\hline & & $b b / b b$ & 1 & 6 & & \\
\hline \multirow[t]{6}{*}{$11 \mathrm{~A} \times \mathrm{W}$} & $a a / a b \times a b / a b$ & $a a / a a$ & 1 & 4 & 1.25 & 0.940 \\
\hline & & $a a / a b$ & 2 & 13 & & \\
\hline & & $a a / b b$ & 1 & 5 & & \\
\hline & & $a b / a a$ & 1 & 7 & & \\
\hline & & $a b / a b$ & 2 & 12 & & \\
\hline & & $a b / b b$ & 1 & 7 & & \\
\hline
\end{tabular}

polyploid complex of Dactylis glomerata (Lumaret, 1986).

As segregation distortion in families of the size raised here can be detected only when it is of an extreme kind (Mulcahy \& Kaplan, 1979), the conclusion that there was no segregation distortion in the families of crosses examined in the present study should be accepted with caution. However, the fact that no deficit or excess of any particular genotype was systematically observed within the 14 families examined is evidence in favour of independent inheritance.

No excess of genotypes identical to the female parent was found among cross- and open-pollinated progenies, suggesting that apomixis did not occur or occurred at an undetectable level in the plants tested. Furthermore, no apomict seedlings were found among the 215 seedlings assayed from the sixth to the tenth families listed in Table 2. In these families any agamospermic seedlings would be 
unambiguously differentiated from those resulting from crossing. Thus, although apomixis has been reported to occur in the Bombacaceae (Baker, 1960; Duncan, 1970; Oliveira et al., 1992), there was no evidence of its occurrence in the present study of $P$. munguba.

The two cytosolic PGI loci of $P$ munguba are likely to be structurally very similar as their homodimeric products associate to form interlocus heterodimeric enzymes. It remains an open question whether the postulated duplication of the $P G I$ gene in $P$. munguba originated by the duplication of a chromosome section by unequal crossing-over (as proposed for Dactylis by Lumaret (1986)), by chromosome rearrangements (as in Clarkia according to Gottlieb (1977)), or as a result of allopolyploidy (as further proposed for Clarkia by Gottlieb \& Higgins, (1984)). The high chromosome number and the occurrence of another duplicated isozyme locus $(P g m)$ in the species (R. Gribel \& R. J. Abbott, personal observation) could suggest that the latter process (allopolyploidy) may be the more likely cause of duplication of the PGI gene in $P$. munguba.

The nondistorted segregation ratios resulting from the crossing experiments further suggest that there is no detectable difference in fitness among the diverse pollen and embryo PGI phenotypes (i.e. PGI phenotypes were not differentially affected by selection at least from pollination to seed maturation). Some other studies, however, have indicated that cytosolic PGI enzymes may vary in adaptive significance in later developmental stages. Zangeri \& Bazzaz (1984) observed in Amaranthus retroflexus that seeds with homozygous genotypes for $P G I$ fast alleles were less affected by low oxygen availability during germination than those homozygous for the slower allele. Riddoch (1993), reviewing studies on a large range of plant and animal species, presented evidence that selection may favour PGI phenotypes with faster enzyme mobility under some environmental conditions such as high temperature, water stress and low oxygen concentration. This is the suite of conditions that $P$. munguba experiences in the seasonally inundated várzea habitat. Thus, it is feasible that PGI variation may influence adaptation in $P$. munguba, and this may account for the predominance of the $P g i-2^{a a}$ Pgi- $3^{a a}$ genotype among trees in the study area. Long-term selection may have favoured individuals homozygous for the faster cytosolic PGI enzyme at both loci. Further experimental studies are required to clarify whether there are any differences in vigour among the $P$. munguba PGI phenotypes raised under várzea conditions.
The results of the genetic analysis of PGI variation in $P$. munguba reported in this paper have confirmed that the cytosolic PGI isozymes can be reliably used as effective genetic markers in future studies of the breeding and mating system of this species. It has been established that: (i) all nine two-locus phenotypes of cytosolic PGI are easily identified; (ii) the two loci are unlinked and may be assayed simultaneously in the same zymogram; (iii) there is no evidence that selection acts differentially among PGI phenotypes from pollination to seed maturation; and (iv) there is no change in enzymatic phenotype related to age (seedling or adult) of the plants. Estimation of outcrossing rates at both marker loci will be reported in another paper together with the findings of other studies on the mating system of $P$. munguba.

\section{Acknowledgements}

We thank Aldenora L. Queiróz for assistance in all field and laboratory activities. We also thank David Forbes for help with isozyme analysis at the beginning of the project. The research was partly supported by the Fundação Botânica Margaret Mee and by the Margaret Mee Amazon Trust. Grant to R. Gribel was provided by The British Council (ref. SCOT/BRA/2273/234/A) and by the Conselho Nacional de Desenvolvimento Científico e Tecnológico, CNPq (proc. 200826/91).

\section{References}

ADAMS, w. T. AND ALLARD, R. w. 1977. Effect of polyploidy on phosphoglucose isomerase diversity in Festuca microstachys. Proc. Nat. Acad. Sci. U.S.A., 74, 1652-1656.

ADAMS, W. T. AND JOLY, R. J. 1980. Genetics of allozyme variants in loblolly pine. J. Hered., 71, 33-40.

AlVAREZ-BUYlla, E. R. AND GARAY, A. A. 1994. Population genetic structure of Cecropia obtusifolia, a tropical pioneer tree species. Evolution, 48, 437-453.

ARAVANOPOUlOS, F. A., ZSUFFA, L. AND CHONG, K. X. 1993. The genetic basis of enzymatic variation in Salix exigua. Hereditas, 119, 77-88.

AUBREVILle, A. 1975. Essais de geophyletique des Bombacacees. Andansonia, ser. 2, 15, 57-64.

BAKER, H. G. 1960. Apomixis and polyembryony in Pakira oleaginea (Bombacaceae). Am. J. Bot., 47, 296-302.

BAUM, D. A. AND OGINUMA, K. 1994. A review of chromosome numbers in Bombacaceae with new counts for Adansonia. Taxon, 43, 11-20.

Boshier, D. H., CHASE, M. R. AND BAWA, K. s. 1995. Population genetics of Cordia alliodora (Boraginaceae), a neotropical tree. 2. Mating system. Am. J. Bot., 82, 
$476-483$.

CAI, Q. AND CHINNAPPA, C. C. 1989. Studies on the Stellaria longipes complex (Caryophyllaceae): characterisation of the genetic basis of isozymes. Can. J. Bot., 67, 2960-2966.

DUNCAN, E. J. 1970. Ovule and embryo ontogenesis in Bombacopsis glabra (Pasq.) A. Ronbins. Ann. Bot., 34, 32-46.

GOLDRING, A., ZAMIR, D. AND DEGANI, C. 1985. Duplicated phosphoglucose isomerase genes in avocado. Theor. Appl. Genet., 71, 491-494.

GOTTLIEB, L. D. 1977. Evidence for duplication and divergence of the structural gene for phosphoglucoisomerase in diploid species of Clarkia. Genetics, 86, 289-307.

GOTTlieb, L. D. 1982. Conservation and duplication of isozymes in plants. Science, 216, 373-380.

GOTTlieb, L. D. AND Higgins, R. C. 1984. Evidence from subunit molecular weight suggests hybridisation was the source of phosphoglucose isomerase gene duplication in Clarkia. Theor. Appl. Genet., 68, 369-373.

GOTTLIEB, L. D. AND WEEDEN, N. F. 1979. Gene duplication and phylogeny in Clarkia. Evolution, 33, 1024-1039.

GOTTlieb, L. D. AND WeEden, N. F. 1981. Correlation between subcellular location and phosphoglucose isomerase variability. Evolution, 35, 1019-1022.

HAll, P., ORRell, L. C. AND BAWA, K. S. 1994. Genetic diversity and mating system in a tropical tree, Carapa guianensis (Meliaceae). Am. J. Bot., 81, 1104-1111.

LACK, A. J. AND KAY, Q. O. N. 1986. Phosphoglucose isomerase (EC 5.3.1.9) isozymes in diploid and tetraploid Polygala species: evidence for gene duplication and diversification. Heredity, 56, 111-118.

LUMARET, R. 1986. Doubled duplication of the structural gene for cytosolic phosphoglucose isomerase in the Dactylis glomerata L. polyploid complex. Mol. Biol. Evol., 3, 499-521.

MITTON, J. B., LINHART, Y. B., STURGEON, K. B. AND HAMRICK, J. L. 1979. Allozyme polymorphisms detected in mature needle tissue of ponderosa pine. J. Hered., 70, 86-89.

MULCAHY, D. L. AND KAPLAN, S. M. 1979. Mendelian ratios despite nonrandom fertilisation? Am. Nat., 113, 419-425.

MURAWSKI, D. A., DAYANANDAN, B. AND BAWA, K. s. 1994. Outcrossing rates of two endemic Shorea species from Sri Lankan tropical rain forests. Biotropica, 26, 23-29.

MURAWSKI, D. A. AND HAMRICK, J. L. 1991. The effect of the density of flowering individuals on the mating systems of nine tropical tree species. Heredity, 67, 167-174.

MURAWSKI, D. A. AND HAMRICK, J. L. 1992. The mating system of Cavanillesia platanifolia under extremes of flowering-tree density: a test of predictions. Biotropica, 24, 99-101.

MURAWSKI, D. A., HAMRICK, J. L. AND FOSTER, R. B. 1990. Mating systems of two Bombacaceous trees of a neotropical moist forest. Oecologia, 82, 501-506.

o'MALlEy, D. M. AND BAWA, K. s. 1987. Mating system of a tropical rain forest tree species. Am. J. Bot., 74,
1143-1149.

O'MALleY, D. M., BUCKLEY, D. P., PRANCE, G. T. AND BAWA, K. S. 1988. Genetics of Brazil nut (Bertholletia excelsa Humb. \& Bonpl.: Lecythidaceae). 2. Mating system. Theor. Appl. Genet., 76, 929-932.

Oliveira, P. E., GIBBS, P. E., BARBOSA, A. A. AND TALAVERA, s. 1992. Contrasting breeding systems in two Eriotheca (Bombacaceae) species of the Brazilian cerrados. Pl. Syst. Evol., 179, 207-219.

PASCUAL, L., MARQUEZ, I. A. AND LOPEZ-ALONSO, D. 1988. Evidence for the duplication of PGI genes in Dipcadi serotinum L. (Liliaceae). Heredity, 60, 247-252.

PIRES, J. M. 1974. Tipos de vegetação da Amazônia. Brasil Florestal, 5, 48-58.

PIRES, J. M. AND PRANCE, G. T. 1985. The vegetation types of the Brazilian Amazon. In: Prance, G. T. and Lovejoy, T. E. (eds) Key Environments Amazonia, pp. 109-145. Pergamon Press, Oxford.

PRENTICE, H. C. AND GILES, B. E. 1993. Genetic determination of isozyme variation in the bladder campions, Silene uniflora and S. vulgaris. Hereditas, 118, 217-227.

RIDDOCH, B. J. 1993. The adaptive significance of electrophoretic mobility in phosphoglucose isomerase (PGI). Biol. J. Linn. Soc., 50, 1-17.

RoByns, A. 1963. Essai de monographie du genre Bombax s. 1. (Bombacaceae). Bull. Jardin Botan. L'Etat Bruxelles, 33, $1-315$

ROVIRA, M., ALETA, N., GERMAIN, E. AND ARUS, P. 1993. Inheritance and linkage relationships of ten isozyme genes in hazelnut. Theor. Appl. Genet., 86, 322-328.

SCHNARRENBERGER, C., TETOUR, M. AND HERBERT, M. 1975. Development and intracellular distribution of enzymes of the oxidative pentose phosphate cycle in radish cotyledons. Plant Physiol., 56, 836-840.

STRAUSS, S. H. AND CONKLE, M. T. 1986. Segregation, linkage, and diversity of allozymes in knobcone pine. Theor. Appl. Genet., 72, 483-493.

STRYER, L. 1988. Biochemistry, 3rd edn. W. H. Freeman, New York.

TORRES, A. M., MAU-LASTOVICKA, T., WILliAMS, T. E. AND SOOST, R. K. 1985. Segregation and linkage of Citrus and Poncirus isozyme genes. J. Hered., 76, 289-294.

WEEDEN, N. F. 1983. Evolution of plant isozymes. In: Tanksley, S. D. and Orton, T. J. (eds) Isozymes in Plant Genetics and Breeding, Part A, pp. 139-156. Elsevier Science, Amsterdam.

WEEDEN, N. F. AND GOTTL1EB, L. D. 1980a. The genetics of chloroplast enzymes. J. Hered., 71, 392-396.

WEEDEN, N. F. AND GOTTLiEB, L. D. 1980b. Isolation of cytoplasmic enzymes from pollen. Plant Physiol., 66, 400-403.

WENDEL, J. F. AND WEEDEN, N. F. 1989. Visualization and interpretation of plant isozymes. In: Soltis, D. E. and Soltis, P. S. (eds) Isozymes in Plant Biology, pp. 5-45. Chapman and Hall, London.

ZANGERI, A. R. AND BAZZAZ, F, A. 1984. Niche partitioning between two phosphoglucoisomerase genotypes in Amaranthus retroflexus. Ecology, 65, 218-222. 